\title{
Macrophages, lymphocytes and MHC II antigen in the ram and the rat testis
}

\author{
P. Pöllänen and S. Maddocks*
}

Department of Anatomy, Institute of Biomedicine, University of Turku, SF-20520 Turku, Finland; and ${ }^{*}$ Department of Animal Sciences, Waite Agricultural Research Institute, University of Adelaide, Glen Osmond, South Australia 5064, Australia

\begin{abstract}
Summary. Macrophages and various subtypes of lymphocytes were identified in the ram and the rat testis by using cytochemical and immunocytochemical techniques. Large and round acid phosphatase-positive cells, notably macrophages, were observed in the rat testis. These cells were absent in the ram testis. Small, elongated cells exhibiting acid phosphatase activity were observed in the testis of both species. The rat testicular interstitium contained $7 \cdot 7$ times as many acid phosphatasepositive cell profiles/surface area unit as did the ram testicular interstitium. $T$ lymphocytes were only occasionally seen in the testis of rat and ram. B lymphocytes were not found in the ram. None of the cell types studied was found in the germinal epithelium.
\end{abstract}

Keywords: macrophages; lymphocytes; MHC II; ram; rat; testis

\section{Introduction}

The testis is considered to be an immunologically privileged site together with the brain, adrenal cortex, cornea and certain other organs (Head \& Billingham, 1985b). Thyroid (Aron et al., 1957), parathyroid (Head et al., 1983a; Head \& Billingham, 1985a) and pancreatic islet (Ferguson \& Scothorne, 1977a, b; Maddocks et al., 1984) allografts and pancreatic islet xenografts (Bobzien $e t$ al., 1983) have been shown to survive in the testes of rodents for remarkably long times. However, Maddocks et al. (1985) reported that thyroid allografts were rejected from the testicular interstitium of rams.

Several factors may contribute to the immunological environment in the testis, including natural immunosuppressive agents (Roubinian et al., 1977; Whitmore et al., 1985; Head \& Billingham, 1985a), lymph drainage (Head et al., 1983b) and the presence or absence of haematogenic elements, such as macrophages and lymphocytes (Pöllänen \& Niemi, 1987). The ram and the rat testis apparently differ from each other in one or several of these factors. The lymph drainage of testis is organized differently in these two species (Fawcett et al., 1973).

Macrophages have been identified in the interstitial tissue of the rat testis (Niemi et al., 1986). They have been shown to contain class II major histocompatibility antigen (Niemi et al., 1986) and immunoglobulin $(\mathrm{Fc})$ receptors on their surface (Miller et al., 1983). The presence of different types of lymphocytes in the testis has not been systematically studied, although there are occasional remarks on their existence in the interstitial compartment (Ritchie et al., 1984; Niemi et al., 1986).

The present study was undertaken to identify macrophages and various classes of lymphocytes in the ram and the rat testis, and to investigate any differences in the cellular composition of the interstitial tissue compartment of these two species, which might account for the different response to allografts. 


\section{Materials and Methods}

Testes removed from ether-anaesthesized adult Wistar rats and pieces of the testes of slaughtered Finnish Landrace rams were frozen in liquid nitrogen and cut into $5 \mu \mathrm{m}$ sections in a cryostat. The sections were dried at room temperature and fixed in cold acetone $\left(-20^{\circ} \mathrm{C}\right)$ for $15 \mathrm{~min}$.

Small pieces of fresh testis tissue were also fixed by immersion in phosphate-buffered $4 \% p$-formaldehyde overnight. The tissues were kept in an arabicum-sucrose medium until they were sectioned in the cryostat.

Cytochemistry. Macrophages were identified by histochemical demonstration of their acid phosphatase activity (Cohn \& Wiener, 1963). The lead salt method of Gomori (1941) and the azo-dye method of Barka \& Andersson (1962) were used. Naphthol-AS-TR phosphate is the substrate in the latter method and hexazotized pararosaniline served as the coupler. In control incubations, the sections were incubated without the substrate.

Immunocytochemistry. The antibodies used are shown in Table 1. The indirect immunoperoxidase method was used to visualize the cell type-specific antigens.

Before incubation with the primary antibodies, non-specific binding sites were blocked with $5 \%$ normal rabbit serum. The primary antibody was allowed to react with the sections for $60 \mathrm{~min}$ at room temperature. The control sections were incubated with normal mouse serum. The sections were then washed with phosphate-buffered saline (PBS, $140 \mathrm{~mm}-\mathrm{NaCl}, 8 \mathrm{~mm}-\mathrm{Na}_{2} \mathrm{HPO}_{4}, 2 \mathrm{~mm}-\mathrm{NaH}_{2} \mathrm{PO}_{4}, \mathrm{pH} 7 \cdot 2$ ) three times. They were incubated with peroxidaseconjugated rabbit anti-mouse immunoglobulins (Dakopatts, Copenhagen, Denmark) diluted 1:50 in PBS containing $1 \%$ bovine serum albumin for $30 \mathrm{~min}$ at room temperature. Sections were finally washed three times with PBS.

The peroxidase activity was demonstrated with diaminobenzidine (Farr \& Nakane, 1981). Mayer's haemalum was used for counterstaining.

Semithin sections. Testes of adult rats and adult rams were removed, perfused through the testicular artery first with saline (rat, $30 \mathrm{sec}$; ram, $2 \mathrm{~min}$ ) and thereafter with $5 \%$ glutaraldehyde $+3 \% \mathrm{p}$-formaldehyde in $0 \cdot 2 \mathrm{M}$-cacodylate buffer, $\mathrm{pH} 7.2$ (rat, $15 \mathrm{~min}$; ram, $60 \mathrm{~min}$ ). Pieces of approximately $1 \mathrm{~mm}^{3}$ in size were sampled and immersed in the

Table 1. The antibodies used to identify various subtypes of lymphocytes and the MHC II antigen-positive cells in the rat and the ram testis

\begin{tabular}{|c|c|c|}
\hline Antibody & Specificity & Reference \\
\hline $\begin{array}{l}\text { MRC Ox } 17^{*} \\
\text { MRC Ox } 19^{*} \\
\text { ST-1† } \\
\text { T-80† }\end{array}$ & $\begin{array}{l}\text { Rat MHC II antigen } \\
\text { Rat thymocytes } \\
\text { All ram T cells } \\
\text { Ram T helper/inducer } \\
\text { lymphocytes } \\
\text { Ram cytotoxic lymphocytes } \\
\text { Ram B cells } \\
\text { Ram class-II major } \\
\text { histocompatibility } \\
\text { antigen }\end{array}$ & $\begin{array}{l}\text { Mayrhofer et al. }(1983) \\
\text { Dallman et al. }(1984) \\
\text { Miyasaka et al. }(1985 \mathrm{a}) \\
\text { Miyasaka et al. }(1983) \\
\text { Miyasaka et al. }(1985 \mathrm{a}) \\
\text { Miyasaka et al. }(1985 \mathrm{a}) \\
\text { Miyasaka et al. }(1985 \mathrm{~b})\end{array}$ \\
\hline
\end{tabular}

*A gift from Dr A. F. Williams, Sir William Dunn School of Pathology, University of Oxford, U.K.

$\dagger$ A gift from Dr M. Miyasaka, School of Medicine, Hamamatsu University, Japan.

Fig. 1. Toluidine blue staining in a semithin plastic section of rat testis. Note the round macrophage (arrow) in the border of lymph sinusoid and the interstitial cell cluster, and its close association with the adjacent Leydig cell. $\times 1280$.

Fig. 2. Toluidine blue staining in a semithin plastic section of ram testis. $\times 1340$.

Fig. 3. Acid phosphatase activity in a para-formaldehyde-fixed frozen section of rat testis. Note the elongated positive cell (arrow). $\times 150$.

Fig. 4. Acid phosphatase activity in a para-formaldehyde-fixed frozen section of ram testis.

Only elongated positive cells are present (arrow). $\times 150$. 


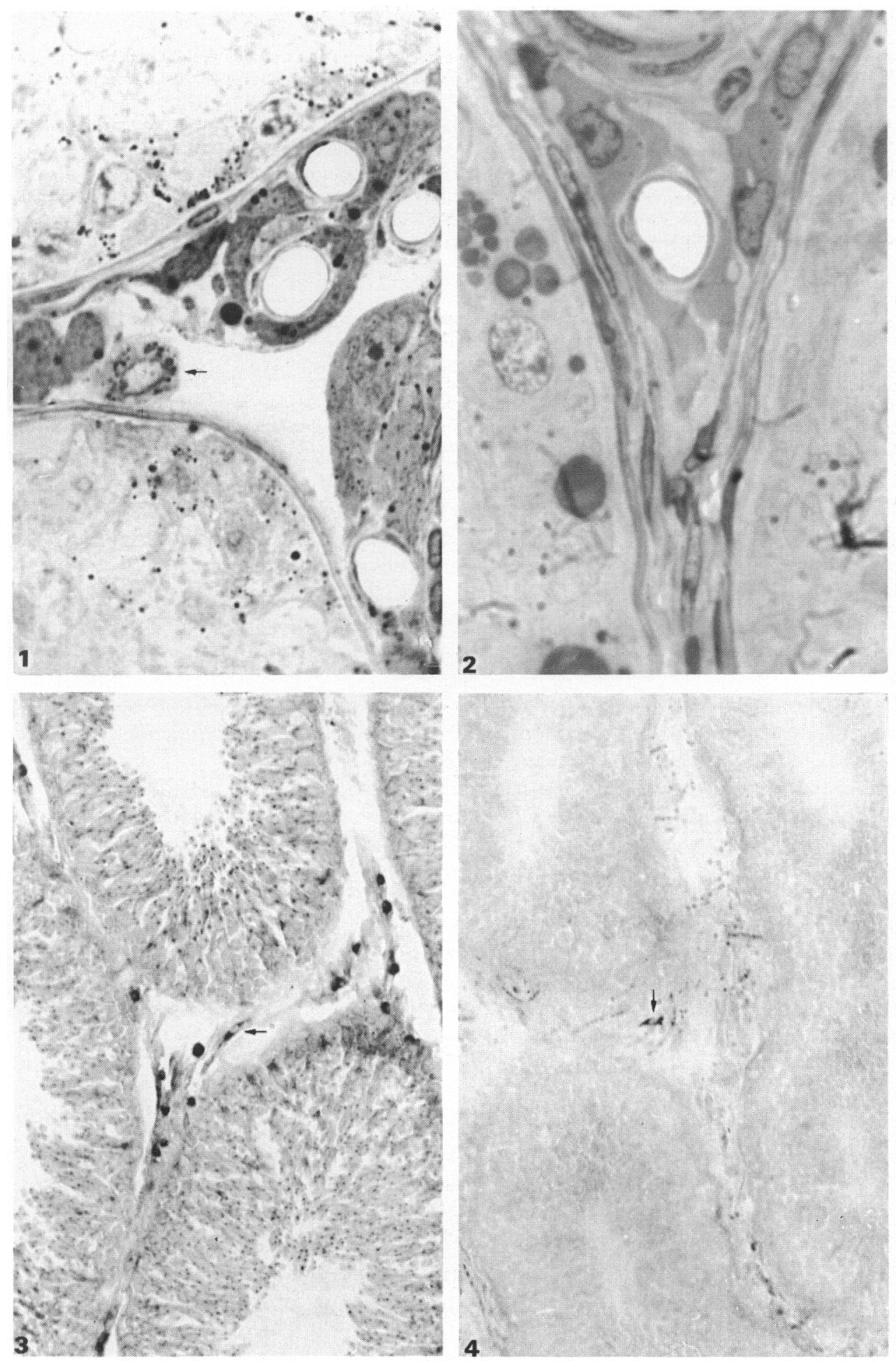


same fixative overnight. The pieces were then washed in buffer, post-fixed in $2 \%$ aqueous $\mathrm{OsO}_{4}$, dehydrated and embedded in Epon. Semithin $(1 \mu \mathrm{m})$ sections were cut, stained with toluidine blue and examined with a light microscope.

Paraffin wax sections. Pieces of ram and rat testicular tissue fixed in $4 \%$ paraformaldehyde or Bouin's fluid were embedded in paraffin wax, sectioned and stained with toluidine blue to reveal metachromatic mast cells.

Morphometry. The number of acid phosphatase positive interstitial cell profiles/surface area unit of whole testis was counted in multiple randomly chosen fields in both the ram and the rat testis. The proportion of the testis made up by interstitial tissue in these species was estimated by point counting in several random microscope fields (Baak \& Oort, 1983). The number of acid phosphatase-positive cell profiles/surface area unit of the interstitium was calculated by dividing the number of positive cell profiles/surface area unit of whole testis with surface area units interstitial tissue/surface area unit of whole testis.

\section{Results}

Cells with morphological characteristics of macrophages were identified in the toluidine bluestained semithin sections of rat testis (Fig. 1). These cells were relatively large and round in shape. The nuclei were round, but had small indentations in the nuclear envelope. The cytoplasm contained numerous densely stained granules and vacuoles. The cells were often associated with Leydig cells. Similar cells were not found in the toluidine blue-stained sections of ram testis (Fig. 2).

In sections treated to reveal acid phosphatase activity numerous large and round positive cells were observed in the rat testis (Fig. 3). These cells were similar in size and shape to the cells observed in the toluidine blue-stained sections. Such cells could not be found in sections revealing acid phosphatase activity of the ram testis. Only a few phosphatase-positive cells were seen in the ram sections and these were elongated in shape (Fig. 4), and contained small cytoplasmic granules. Occasional elongated positive cells were also seen in the rat testis (Fig. 3). The control sections were negative.

In the toluidine blue-stained semithin sections of the ram testis, the nuclei of the elongated cells were irregular and appeared light in colour. The thin cytoplasm contained numerous granules. The features of the elongated cells in the rat testis were similar.

The round acid phosphatase-positive cells were scattered throughout the interstitium of the rat testis. The elongated cells found in both the ram and the rat testis were seen exclusively in the interstitial tissue, although occasional positive cells were found in close association with the lamina propria of the seminiferous tubules. Macrophages were not observed inside the tubules in either of these species.

The rat testicular interstitium contained 7.7 times as many acid phosphatase-positive cell profiles per area as did the ram testis (Table 2 ). The proportion of the testis made up by interstitial tissue was $2 \cdot 2$ times higher in the ram testis than in the rat testis (Table 2).

T-lymphocytes (ram, ST-1+, rat, MRC Ox 19+) were only occasionally observed in the testes of rats and rams (Figs 5, 6). The few T-lymphocytes seen were usually close to the blood vessels

Fig. 5. Indirect immunoperoxidase staining for MRC Ox 19-positive T lymphocytes (arrows) in an acetone-fixed frozen section of rat testis. Counterstained with Mayer's haemalum, $\times 500$.

Fig. 6. Indirect immunoperoxidase staining for ST-1 positive T lymphocytes in an acetone-fixed frozen section of ram testis. Counterstained with Mayer's haemalum, $\times 200$.

Fig. 7. Indirect immunoperoxidase staining for MRC Ox 17-positive class-II MHC antigenexpressing cells in an acetone-fixed frozen section of rat testis. Counterstained with Mayer's haemalum, $\times 150$.

Fig. 8. Indirect immunoperoxidase staining for SB-1 positive cells in an acetone-fixed frozen section of ram testis. $\times 150$. 

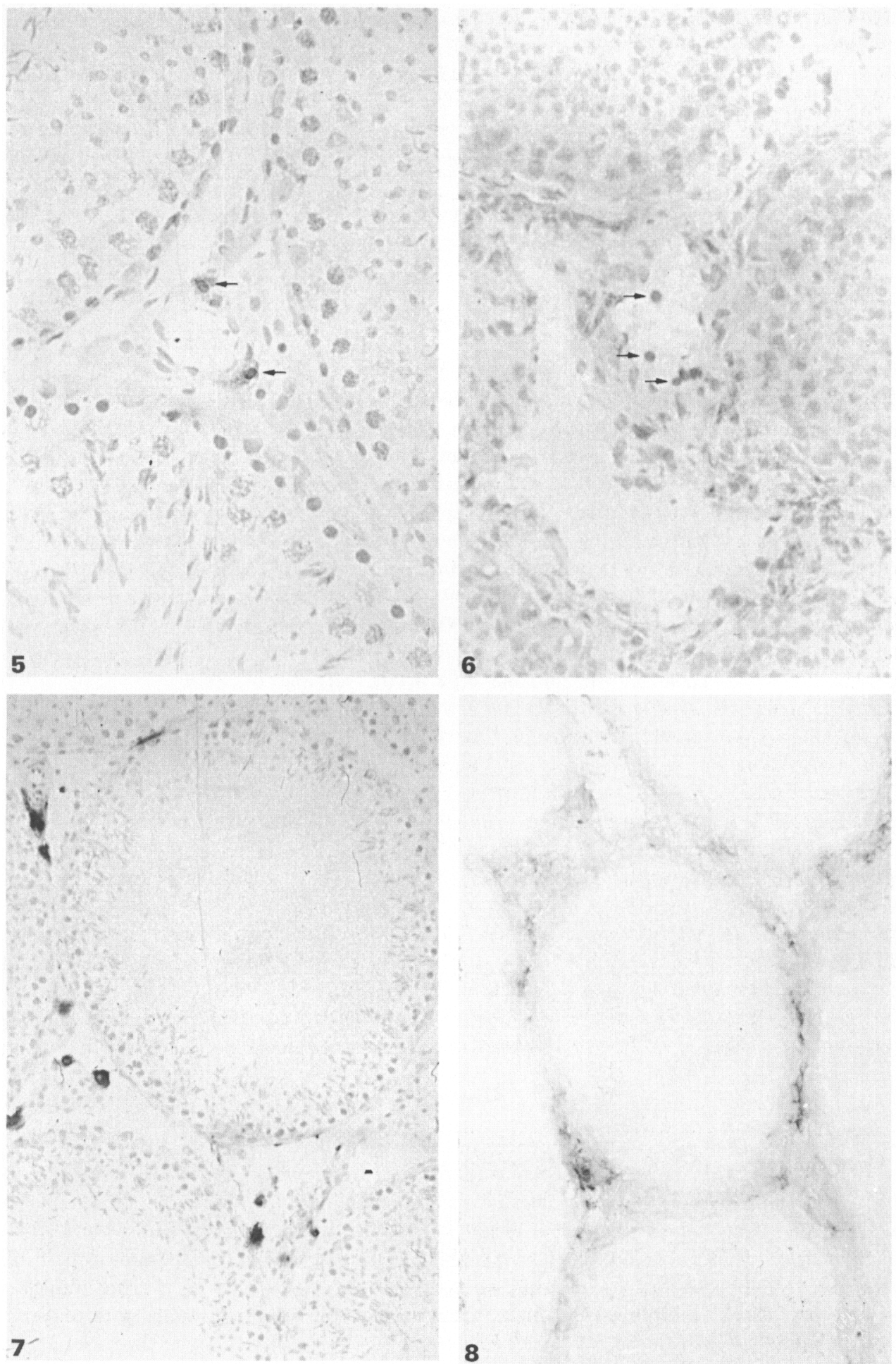
Table 2. Acid phosphatase-positive cell profiles/surface area unit in the interstitium of the ram and the rat testis

\begin{tabular}{lcc}
\hline & Rat $(n=10)$ & Ram $(n=10)$ \\
\hline $\begin{array}{l}\text { Acid phosphatase + ve cell profiles/surface area unit of } \\
\text { whole testis (mean } \pm \text { s.d.), }\end{array}$ & $2.7 \pm 1 \cdot 8$ & $0.8 \pm 1.0$ \\
$\begin{array}{l}\text { Surface area units of interstitium/surface area unit of whole } \\
\text { testis (mean } \pm \text { s.d.) }\end{array}$ & $0.0086 \pm 0.0047$ & $0.0195 \pm 0.0064$ \\
$\begin{array}{l}\text { Acid phosphatase + ve cell profiles/surface area unit of } \\
\text { interstitium }\end{array}$ & 314.0 & 41.0 \\
$\begin{array}{l}\text { Relation of positive cell profiles/surface area unit of } \\
\text { interstitium (rat to ram) }\end{array}$ & $7 \cdot 7$ & \\
\hline
\end{tabular}

and were never seen in the tubules. Very few $\mathrm{T}$ helper/inducer $(\mathrm{T} 80+)$ or cytotoxic $(\mathrm{ST}-8+)$ lymphocytes were seen in the ram testis and no B-lymphocytes $(\mathrm{E}-53+)$ were found.

The class-II major histocompatibility antigen (MRC Ox 19) was found on the endothelial cells and macrophages in rat testis (Fig. 7). In ram testis the SB-1 antigen was localized on the endothelial cells and occasional interstitial cells (Fig. 8). The rat seminiferous epithelium did not stain positive for the class-II major histocompatibility antigen and in the ram the germinal epithelium was also negative for the SB-1 antigen (Fig. 8). The control sections were negative.

In the toluidine blue-stained paraffin wax sections of ram and rat testicular tissue, mast cells, as judged by the presence of metachromasia, were not found.

The various immune cells found in the ram and the rat testis are summarized in Table 3.

Table 3. The immune cells in the rat and the ram testicular parenchyma

\begin{tabular}{lcc}
\hline \multicolumn{1}{c}{ Cell type } & Rat testis & Ram testis \\
\hline Macrophages & & \\
$\quad$ Large and round & + & - \\
Small and elongated & & \\
$\quad$ Acid phosphatase + ve cells & + & + \\
Lymphocytes & + & + \\
$\quad$ T cells & ND & - \\
B cells & $\pm^{*}$ & - \\
Mast cells & & \\
\hline ND = not determined. & \\
${ }^{*}$ In the vicinity of testicular artery (Sowerbutts et al., 1986).
\end{tabular}

\section{Discussion}

The present findings demonstrate differences in the magnitude and composition of the testicular macrophage population between the ram and the rat. In previous reports (Christensen, 1975; Bergh, 1985; Niemi et al., 1986), cells identified as macrophages by various means comprised about $25 \%$ of all the interstitial cells in the rat testis. The results obtained in this study using the cytochemical demonstration of acid phosphatase activity (Cohn \& Wiener, 1963) confirm these earlier reports. However, in contrast to these previous reports we have observed two morphologically different types of cells exhibiting acid phosphatase activity in the rat testis: large round macrophages and small elongated cells. The latter cells resemble the tissue histiocytes described by Stieve (1930) and may represent the stem cells of testicular macrophages and Leydig cells (Clegg \& MacMillan, 1965). Similar elongated cells were present in the ram testis. While mast cells also 
exhibit acid phosphatase activity (Paff et al., 1947), and they have been found in the rat testicular capsule in the vicinity of the testicular artery (Sowerbutts et al., 1986) and in the human testis (Hermo \& Lalli, 1978; Nistal et al., 1984), no cells containing metachromatic granules were observed in the toluidine blue-stained paraffin wax sections of the ram or the rat testicular parenchyma.

Two types of phagocytosing cells can be observed in another immunologically privileged site, the adrenal cortex (Kerr, 1972). In the deep adrenal cortex, cells different from monocytes are involved in the deletion of degenerating steroid-secreting cells (Kerr et al., 1972). These cells respond to ACTH withdrawal by increasing destruction of adrenocortical cells (Wyllie et al., 1973). The testicular macrophages are often found in close association with the Leydig cells (Bergh, 1985; Niemi et al., 1986), they have been reported to respond to FSH stimulation (Yee \& Hutson, 1985) and phagocytose Leydig cells after ethane dimethane sulphonate (EDS) administration (Jackson $e t$ al., 1986; Kerr et al., 1986; Morris et al., 1986). The round testicular macrophages, like the nonmonocyte phagocytosing cells in the adrenal cortex, might delete degenerating Leydig cells in response to changes in hormonal levels.

Born \& Wekerle (1982) reported that the Leydig cells non-specifically suppressed mitogen- or allogeneic cell-induced lymphoproliferation. They suggested that the Leydig cells, which have also been reported to adhere non-specifically to lymphocytes and leukaemic cells (Rivenzon et al., 1974; Born \& Wekerle, 1982), would provide an immunologically weak zone in the testicular interstitium, a region in which the leukaemic cells often first reappear after chemotherapy (Saiontz et al., 1978). However, the Leydig cell preparations of Born \& Wekerle (1982) were partly characterized by criteria that are also attributable to testicular macrophages (Molenaar et al., 1984), and the preparations contained $10-20 \%$ non-Leydig cells. Spleen macrophages have been shown to express immunosuppressive activity in normal (Oehler et al., 1977) and leukaemic (Glaser et al., 1975) rats, and it is possible that testicular macrophages contaminating the Leydig cell preparations were responsible for the immunosuppression reported.

The round testicular macrophages in the rat express the class-II MHC antigen. The presence of SB-1 antigen in the ram is well correlated with the presence of MHC II antigen (M. Miyasaka, personal communication), and cells bearing the SB-1 antigen are occasionally seen in the ram testis. This suggests that the small elongated cells expressing acid phosphatase activity in the ram testis are possibly macrophages capable of antigen expression to the T-inducer lymphocytes. The absence of class-II antigen from the germinal epithelium in both species may assist in protecting the immunologically foreign germ cells from immune surveillance, and make the initiation of an immune response difficult. The human germinal epithelium is also devoid of class-II MHC antigen (Pöllänen \& Niemi, 1987).

$T$ lymphocytes were found in the ram and the rat testis, although they were few in number. It is therefore unlikely that the difference in allograft survival in the testes of the ram and the rat is due to a difference in lymphocyte migration to the testicular parenchyma. This view is supported by the observation that long-established intratesticular allografts in the rat are promptly rejected after specific acute immunization of the host (Head et al., 1983a).

The reason for the survival of transplants in the rat testis is still obscure. However, the present results demonstrate differences in the cellular composition of the testicular interstitium between ram and rat (Tables 2 and 3). It is known that macrophages (Oehler et al., 1977) and supernatants from macrophage cultures (Keller, 1975) can inhibit lymphocyte proliferation in vitro. There is still the possibility that the macrophages in the rat testis contribute to the immune privilege of this site by modifying directly or indirectly the activity of Leydig cells.

We thank Dr M. Niemi (Turku, Finland) for valuable advice; and Dr A. F. Williams (Oxford, U.K.) and Dr M. Miyasaka (Hamamatsu, Japan) for the antibodies. S.M. was the recipient of an Australian Wool Corporation Post-Graduate Scholarship. This work was also supported by a grant from the Finnish University Society in Turku. 


\section{References}

Aron, M., Marescaux, J. \& Petrovic, A. (1957) Greffes homoplastiques chez le mammiferes. Colloq. Int. C.N.R.S. 78, 25-33.

Baak, J.P.A. \& Oort, J. (1983) Practical morphometry. In Morphometry in Diagnostic Pathology, pp. 159-181. Eds J. P. Baak \& J. Oort. Springer-Verlag, Berlin.

Barka, T. \& Anderson, P. (1962) Histochemical methods for acid phosphatase using hexazonium pararosaniline as coupler. J. Histochem. Cytochem. 10, 741-750.

Bergh, A. (1985) Effect of cryptorchidism on the morphology of testicular macrophages: evidence for a Leydig cell-macrophage interaction in the rat testis. Int. J. Androl. 8, 86-96.

Bobzien, B., Yasunami, Y., Majercik, M., Lacy, P.E. \& Davie, J.M. (1983) Intratesticular transplants of islet xenografts (rat to mouse). Diabetes 32, 213-216.

Born, W. \& Wekerle, H. (1982) Leydig cells nonspecifically suppress lymphoproliferation in vitro: implications for the testis as an immunologically privileged site. Am. J. Reprod. Immunol. 2, 291-295.

Christensen, A.K. (1975) Leydig cells. In Handbook of Physiology, Section 7, Vol. 5, pp. 57-94. American Physiological Society, Washington D.C.

Clegg, E.J. \& MacMillan, E.W. (1965) The phagocytic nature of Schiff-positive interstitial cells in the rat testis. J. Endocr. 31, 299-300.

Cohn, Z.A. \& Wiener, E. (1963) The particulate hydrolases of macrophages. I. Comparative enzymology, isolation, and properties. J. exp. Med. 118, 991-1008.

Dallman, M.T., Thomas, M.L. \& Green, T.R. (1984) A monoclonal antibody that labels rat $\mathrm{T}$ lymphocytes and augments in vitro proliferative responses. Eur. $J$. Immunol. 14, 260-267.

Farr, A.G. \& Nakane, P.K. (1981) Immunocytochemistry with enzyme labelled antibodies: a brief review. $J$. Immunol. Methods 47, 129-144.

Fawcett, D.F., Neaves, W.B. \& Flores, M.N. (1973) Comparative observations on intertubular lymphatics and the organization of the interstitial tissue of the mammalian testis. Biol. Reprod. 9, 500-532.

Ferguson, J. \& Scothorne, R.S. (1977a) Extended survival of pancreatic islet allografts in the testis of guinea pigs. J. Anat. 124, 1-8.

Ferguson, J. \& Scothorne, R.S. (1977b) Further studies on the transplantation of isolated pancreatic islets. $J$. Anat. 124, 9-20.

Glaser, M., Kirschner, H. \& Herberman, R.B. (1975) Inhibition of in vitro lymphoproliferative responses to tumor-associated antigens by suppressor cells from rats bearing progressively growing gross leukemia-virus induced tumors. Int. J. Cancer 16, 384-393.

Gomori, G. (1941) Distribution of acid phosphatases in the tissues under normal and under pathologic conditions. Arch. Path. 32, 189-199.

Head, J.R. \& Billingham, R.E. (1985a) Immune privilege in the testis II. Evaluation of potential local factors. Transplantation 40, 269-275.

Head, J.R. \& Billingham, R.E. (1985b) Immunologically privileged sites in transplantation immunology and oncology. Perspectives in Biology and Medicine 29, 115-131.

Head, J.R., Neaves, W.B. \& Billingham, R.E. (1983a)
Immune privilege in the testis. I. Basic parameters of allograft survival. Transplantation 36, 423-431.

Head, J.R., Neaves, W.B. \& Billingham, R.E. (1983b) Reconsideration of the lymphatic drainage of the rat testis. Transplantation 35, 91-95.

Hermo, L. \& Lalli, M. (1978) Monocytes and mast cells in the limiting membrane of human seminiferous tubules. Biol. Reprod. 19, 92-100.

Jackson, N.C., Jackson, H., Shanks, J.H., Dixon, J.S. \& Lendon, R.G. (1986) Study using in-vivo binding of ${ }^{125}$ I-labelled hCG, light and electron microscopy of the reproduction of rat Leydig cells after destruction due to administration of ethylene-1,2-dimethanesulphonate. J. Reprod. Fert. 76, 1-10.

Keller, R. (1975) Major changes in lymphocyte proliferation evoked by activated macrophages. Cell. Immunol. 17, 542-551.

Kerr, J.B., Bartlett, J.M.S. \& Donachie, K. (1986) Acute response of testicular interstitial tissue in rats to the cytotoxic drug ethane dimethanesulphonate. Cell Tiss. Res. 243, 405-414.

Kerr, J.F.R. (1972) Shrinkage necrosis of adrenal cortical cells. J. Path. 107, 217-219.

Kerr, J.F.R., Wyllie, A.H. \& Currie, A.R. (1972) Apoptosis: A basic biological phenomenon with wide-ranging implications in tissue kinetics. $\mathrm{Br} . \mathrm{J}$. Cancer 26, 239-257.

Maddocks, S., Oliver, J.R. \& Setchell, B.P. (1984) The survival and function of isolated pancreatic islets of Langerhans transplanted into the testis of adult rats and their effect on the testis. I.N.S.E.R.M. Colloq. 123, 497-502.

Maddocks, S., Cormack, J. \& Setchell, B.P. (1985) The failure of thyroid allografts in the ovine testis. Proc. Austr. Soc. Reprod. Biol. 17, 51, Abstr.

Mayrhofer, G., Pugh, C.W. \& Barlay, A.N. (1983) The distribution, ontogeny and origin in the rat of Iapositive cells with dendritic morphology and Ia antigen in epithelia, with special reference to the intestine. Eur. J. Immunol. 13, 112-122.

Miller, S.C., Bowman, B.M. \& Rowland, G.H. (1983) Structure, cytochemistry, endocytic activity and immunoglobulin (Fc) receptors of rat testicular interstitial-tissue macrophages. Am. J. Anat. 168, $1-13$.

Miyasaka, M., Heron, I., Dudler, L., Cahill, R.N.P., Forni, L., Kimak, T. \& Trnka, Z. (1983) Studies on the differentiation of $T$ lymphocytes in sheep. $I$. Recognition of a sheep T-lymphocyte differentiation antigen by monoclonal antibody T-80. Immunology 49, 545-553.

Miyasaka, M., Beya, M.-F., Dudler, L., Parisot, R., Ezaki, T. \& Trnka, Z. (1985a) Studies on lymphocyte differentiation and migration in sheep by the use of monoclonal antibodies. In Immunology of the Sheep, pp. 68-87. Eds B. Morris \& M. Miyasaka. Editiones Roche, Basel.

Miyasaka, M., Reynolds, J., Dudler, L., Beya, M.-F., Leiserson, W. \& Trnka, Z. (1985b) Differentiation of B lymphocytes in sheep. II. Surface phenotype of B cells leaving the "bursa-equivalent" lymphoid tissue of sheep, ileal Peyer's patches. Adv. exp. Med. Biol. 186, 119-126. 
Molenaar, R., Rommerts, F.F.G. \& van der Molen, H. (1984) Characteristics of Leydig cells and macrophages from developing testicular cells. Ann. N.Y. Acad. Sci. 438, 618-621.

Morris, I.D., Phillips, D.M. \& Bardin, C.W. (1986) Ethylene dimethanesulfonate destroys Leydig cells in the rat testis. Endocrinology 118, 709-719.

Niemi, M., Sharpe, R.M. \& Brown, W.R.A. (1986) Macrophages in the interstitial tissue of the rat testis. Cell Tiss. Res. 243, 337-344.

Nistal, M., Santamaria, L. \& Paniagua, R. (1984) Mast cells in the human testis and epididymis from birth to adulthood. Acta anat. 119, 155-160.

Oehler, J.R., Herberman, R.B., Campbell, D.A., Jr \& Djeu, J.Y. (1977) Inhibition of rat mixed lymphocyte cultures by suppressor macrophages. Cell. Immunol. 29, 238-250.

Paff, G.H., Montagna, W. \& Bloom, F. (1947) Cytochemical studies of normal and tumor mast cells in vitro. Cancer Res. 7, 798-801.

Pöllänen, P. \& Niemi, M. (1987) Immunohistochemical identification of macrophages, lymphoid cells and HLA antigens in the human testis. Int. J. Androl. 10, $37-42$.

Ritchie, A.W.S., Hargreave, T.B., James, K. \& Chisholm, G.D. (1984) Intraepithelial lymphocytes in the normal epididymis. A mechanism for tolerance to sperm auto-antigens. Br. J. Urol. 56, 79-83.

Rivenzon, A., Rivenzon, M. \& Madden, R.E. (1974) Spontaneous adherence and rosette formation of lymphocytes to Leydig cells: an in vitro technique. Cell. Immunol. 14, $411-416$.
Roubinian, J.R., Papoian, R. \& Talal, N. (1977) Androgenic hormones modulate autoantibody responses and improve survival in murine lupus. J. clin. Invest. 59, $1066-1070$.

Saiontz, H.I., Gilchrist, G.S., Smithson, W.A., Burgert, E.O. \& Cupps, R.E. (1978) Testicular relapse in childhood leukemia. Mayo Clin. Proc. 53, 212-216.

Sowerbutts, S.F., Jarvis, L.G. \& Setchell, B.P. (1986) The increase in testicular vascular permeability induced by human chorionic gonadotrophin involves 5hydroxytryptamine and possibly oestrogens, but not testosterone, prostaglandins, histamine or bradykinin. Austr. J. exp. Biol. Med. Sci. 64, 137-147.

Stieve, H. (1930) Das Zwischengewebe. In Handbuch der Mikroskopischen Anatomie des Menschen, vol. 7, part 2, pp. 61-77. Ed. W. von Möllendorf. Springer, Berlin.

Whitmore, W.F., Karsh, L. \& Gittes, R.F. (1985) The role of germinal epithelium and spermatogenesis in the privileged survival of intratesticular grafts. J. Urol. 134, 782-786.

Wyllie, A.H., Kerr, J.F.R., Macaskill, I.A.M. \& Currie, A.R. (1973) Adrenocortical cell deletion: the role of ACTH. J. Path. 111, 8594.

Yee, J.B. \& Hutson, J.C. (1985) Biochemical consequences of follicle-stimulating hormone binding to testicular macrophages in culture. Biol. Reprod. 32, 872-879.

Received 18 February 1987 